\title{
THE LAW OF STATE-OWNED ENTERPRISES IN A SOCIALIST STATE
}

\author{
Stephan Supranowitz*
}

\section{INTRODUCTION}

The legal status of state-owned enterprises in the socialist states reflects their position in the economic system of these countries and has to be examined in the context of this economic system and its development tendencies. The socialist economic system represents a new type of the organization of the production process, based on novel economic, political, and social conditions. Within this economic system, the economic organs of the state are the specific organizations for the utilization and administration of society's productive resources. Their character is therefore determined by the economic rules governing the functions of public property in an economy where the decisive means of production are socialized. In the following, this interconnection will be demonstrated by reference to the German Democratic Republic.

\section{The Nature of Public Ownership}

In the German Democratic Republic, the most important means of production are owned by the nation. ${ }^{1}$ National property is not subject to the disposition of private individuals, and is exclusively at the disposal of the working class organized in the socialist state. National property thus constitutes a uniform fund, represented in its entirety by the state. The economic task of the state is the utilization, improvement, and protection of national property within the framework of the country's economy, and in accordance with the principles of socialist economic management which pursues the policy of increasingly improving the supply of all needs of the population. From this, it necessarily follows that the state is the sole owner of all national property. As the owner of the most important means of production, and in pursuance of the above-mentioned basic purpose, the state establishes a system of specific organizations, i.e., public economic organs. The economic and legal principles of the organization and administration of national property therefore depend

- Dr.iur. I960, Humboldt University of Berlin, Germany. Research Assistant, Institute of Civil Law, Law Faculty of the Humboldt University of Berlin, Germany.

1 German Democratic Republic Const. arts. 25, 27, 28; English translation in 2 Amos J. Peaslee, Constitutions of Nations 59, 63-64 (2d ed. 1956) [hereinafter cited as Peaslee]. As hercinafter used, "national property" refers to state-owned property (Volkseigentum); "national enterprises" are stateowned enterprises (Volkseigene Betriebe; VEB). For descriptions of the development of national property in East Germany since I945, see W. Krause, Die ENTstehung des Volkseigentums in der Industrie der DDR (1958); S. Doernberg, Die Geburt eines neuen Deutschrands (1959). 
upon the basic conditions of economic development and the present stage of the evolution of modern social resources of production. ${ }^{2}$

As units of a uniform socialist economic system, the national enterprises are in essence economic organs of the state. Their basic character is determined by the fact that they are established by the socialist state on the basis of a uniform system of national property, and that in their economic and organizational activities, they perform public functions in accordance with state planning and direction. The purpose of their establishment is the legally and economically independent utilization and administration, in accordance with the national economic plan and in the interest of the national economy, of a specific portion of national property attributed to each individual enterprise by the state. The latter remains the sole owner of all property which is subject to the administration of the national enterprises. ${ }^{3}$ Consequently, the national enterprises are accountable for all their economic activities to their corresponding organs of state economic management.

There are certain specific forms for the realization of these general principles in the various branches of the economy, and at different levels of the economic process. In the following, discussion is limited to the relations between centrally administered industrial national enterprises ${ }^{4}$ and their immediately superior organs of economic administration.

\section{II}

\section{Administrative Control, Over National Enterprises}

The economically most important national enterprises are directly subject to supervision by Associations of National Enterprises. ${ }^{5}$ These Associations are organs

This does not only follow from the special conditions of development in East Germany. A comparative survey shows that the same principles of organization and management of national enterprises obtain in all socialist states. See, e.g., A. V. Venedirtov, State-Owned Socialist Property (I948; in Russian); V. Knapp, The Law of Property in a Peoples' Democract (I952; in Czech); $\$ \$ 88$ and 89 of the Hungarian Civil Code of 1959. The importanice of these principles for the political and economic development of socialist states is reflected by their incorporation into the constitutions of these states. Sec, e.g., Constitution of the U.S.S.R., arts. 4, 5, 6, in 3 Peastee 485; Constitution of the Chinese Peoples' Republic, art. 6; Constitution of the Peoples' Republic of Albania, art. 7; Constitution of the Polish Peoples' Republic, arts. 7 and 8, in 3 PeAsLeE 187 , I89; Constitution of the Peoples' Republic of Bulgaria, arts. 6-8, in I PeAstee 262, 262-63; Constitution of the Rumanian Peoples' Republic, arts. 6 and 7 , in 3 Peaslee 239, 240; Constitution of the Hungarian Peoples' Republic, arts. 4-6, in 2 Peaslee $185,185-86$.

${ }^{3}$ See Knapp, Zur operativen Verwaltung des Nationalvermögens, [1955] STAAT UND RECHT 608, 622, where this relationship between the state and individual enterprises is aptly referred to as the dialectical relationship between the whole and its constituent parts.

- Centrally administered national enterprises are directly subject to the direction of the central organs of the state and other appropriate central agencies. Numerically, there are many more national enterprises directed by local organs of state power in the districts, counties, and municipalities; but production-wise, the centrally administered enterprises are by far the most important. Thus, in 1959, there were 346 centrally administered national enterprises engaged in basic industry, with a gross production of $15,630,970$, as against 675 locally administered enterprises with a gross production of $2,357,605$ (in units of fixed plan prices of $D M 1,000 \mathrm{cach}$ ). Corresponding figures for metallurgical industry were 658:708 and $17,498,233: 2,095,380$; and in light industry: $124: 672$ and 7,883,281:3,120,470. 5 STATISTISChes Jahrbuch DER Deutschen Demokratischen Republik: 1959, at 296 (I960).

${ }^{8}$ Law concerning the improvement and simplification of the operation of state administration in the German Democratic Republic, of Feb. II, 1958, [1958] I GesetzblatT der Deutschen Demokratischen REPUBLIK [hercinafter cited as GBl.DDR] II7; Decree on Charters of Associations of National Enterprises connected with the State Planning Commission, of Feb. 13, I958, id. at I49. 
of economic management, and exercise immediate operational directive powers over the national enterprises.

One of the most important functions of the Associations of National Enterprises is the preparation of long-range and one-year plans for the industry which is subject to their direction. This planning covers all aspects of economic development, especially production, supply, investments, labor, and financing, as well as basic and development research. The Associations of National Enterprises prepare their plans on the basis of proposals submitted by individual national enterprises for their respective sectors in accordance with predetermined guideposts. The Associations have the duty of exercising their planning functions in close cooperation with the managerial staffs and the labor organizations of the enterprises concerned. They are especially obliged to instruct and advise individual enterprises in preparing both the proposed plan and the final work schedule.

This relationship between national enterprises and the Associations of National Enterprises is supplemented by the duty of the Associations to instruct and advise the enterprises in the execution of the plans, and to supervise their activities in order to insure performance according to schedule. The nature of the management powers exercised by organs of economic management over individual national enterprises is also characterized by the obligation of the Associations of National Enterprises to encourage the introduction and constant improvement of modern technological processes, to aid in the improvement of the quality of products, and to direct and control the activities of national enterprises in the fields of sales, supply, bookkeeping, and finance. ${ }^{7}$

'These interrelations between Associations of National Enterprises and centrally administered national enterprises constitute but one phase of the process of economic planning. It therefore secms advisable to give a brief survey of the entire planning process, so far as it is material in this connection. The elaboration of economic plans commences each year with the tranismittal of economic policy directives from the State Planning Commission to the individual Associations of National Enterprises. These contain numerical guideposts for enterprises subject to the various Associations; such guideposts are fixed in accordance with perspective plans which cover several years. See Regulation concerning the basic economic planning methods in the German Democratic Republic, of July 4, 1959, [1959] Sp'L ED. GBl.DDR $\S 277$ a (effective as of 1960). On the basis of these guideposts, both the Associations and the individual enterprises prepare plan proposals for their respective sectors of production. These proposals are calculated and coordinated with all necessary investments even at this phase of drafting the plan. The plan proposal of the individual enterprise is discussed in many different ways with the workers of the enterprise and, together with their written comments, is transferred to the proper Assosiation. The Association, in turn, submits its plan proposal (the sum of the proposals of the individual enterprises subject to its jurisdiction) to the State Planning Commission. The latter claborates a draft economic plan which, after having been approved by the Council of Ministers, is enacted into law by Parliament. Then; the State Planning Commission, the Associations, and the individual national enterprises in turn allocate planning tasks in such a manner that each Association and individual enterprise is given a binding production quota. These quotas determine the economic activities of the enterprises concerned, and are the basis for the elaboration of work schedules. Sec generally H. ARNOrD, H.

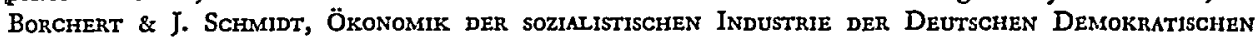
Republik 217 et seq. (6th ed. I96I); S. E. Kamenitzer, Organisation und Planung des sozialistischen INDUSTRIEBETRIEBES (1953).

${ }^{7}$ For details, see Decree concerning the organization of economic planning, of Feb. 13, 1958, Pt. V, [1958] I GBl.DDR 125, 128; Regulation concerning the basic economic planning methods in the German Democratic Republic, op. cit. stupra note 6; Decree on Charters of Associations of National Enterprises, op. cit. supra note $5, \S 3-8$. 
Within the scope of their duties to plan, direct, and control the national enterprises subject to their jurisdiction, the Associations of National Enterprises have the power of issuing binding directives. This power, however, is exercised in accordance with the principle of democratic centralism, which is at the base of the operation of the socialist economy. Therefore, cooperation and consultation with the managing staffs and the labor representatives of individual enterprises is an integral concomitant of central supervision. It follows that the binding directives received by national enterprises from their respective superior organs of economic management within the scope of applicable plans are not external, arbitrary acts of interference in the economically and legally independent activtities of national enterprises, but jointly elaborated specific expressions of planning tasks which are binding upon both the Association and the individual enterprise concerned. The relations between the Associations of National Enterprises and the individual enterprises subject to their jurisdiction are further based on the policy of strengthening the economic independence of individual national enterprises within the framework of the state economic plan, and of increasing their individual responsibilities.

\section{III}

\section{The Powers of National Enterprises}

In accordance with this basic rule of the distribution of managerial authority within the socialist sector of the economy, the legal status of individual national enterprises is characterized by the principle of managerial and legal independence in fulfillment of all tasks under relevant economic plans. ${ }^{9}$ The national enterprises thus have all the rights and obligations necessary to enable them to take, in their own names, all economic and legal actions necessary to attain their plan-prescribed objectives.

This managerial and legal independence of national enterprises is an essential principle of a socialist economy uniformly organized and managed in accordance with an economic master plan. For central management and planning are based on the rule that in accomplishing the tasks allotted to them by the economic plan, the national enterprises have individual discretion and responsibility in the choice of methods and means of organizing all necessary supply, production, and sales activities. This independence of national enterprises in turn enables the socialist state to encourage creative action and responsible managerial policies by individual works, management staffs, and labor organizations within the framework of a centrally

\footnotetext{
${ }^{8} \mathrm{Law}$ concerning the improvement and simplification of the operation of state administration, op. cit. supra note $5, \S 2$, para. I (5); Decree concerning the organization of economic planning, op. cit. supra note $7, \mathrm{Pt} . \mathrm{V}$, para. 4 .

- Charter [Statut] of centrally administered enterprises of the national industry of the German Democratic Republic, of Aug. 7, I952, [1952] Ministerialblatt der Deutschen Demorratischen REPUBLIK I37; Decree concerning measures for the introduction of the principle of economic accounting in national enterprises, of March 20, 1952, [1952] GBI.DDR 225; $f$. H. KLEINE (ED.), DAs ZivilrechT der Deutschen Demokratischen Republix, Allgemerner Teil i8o et seq. (1954); Laptjew, Rechtsfragen der Leitung der Industriebetriebe in der Sowjetunion, [1959] STAAT UND RECHT 62; Knapp, supra note 3 , at 608 et seq.
} 
planned and directed economy. This indicates that the principle of the managerial and legal independence of national enterprises is not a negation of central planning and production, but complements the latter.

One of the chief manifestations of the managerial and legal independence of individual national enterprises is the fact that at the time of their establishment, the state transfers to their independent administration the material and financial resources necessary for the fulfillment of their tasks. ${ }^{10}$ By this transfer, the state does not relinquish its legal title to such property and funds, but merely vests in the national enterprises the right of possessing, utilizing, and disposing of the same in the execution of their plan-conferred tasks. Thus, the administration of national property by the national enterprises consists of the exercise of the state's powers of ownership by each respective national enterprise in its own name. ${ }^{11}$

\section{Powers of utilization and disposal}

The power of national enterprises to utilize national property which is subject to their jurisdiction consists of the right to make optimal efficient use of such property in the production process, and in accordance with the economic plan. However, state economic planning also calls for the actual utilization of available resources in the production process. The power of national enterprises to utilize public property is therefore coupled with the legal duty to utilize such property in accordance with the economic plan. Furthermore, this power exists only with respect to property which is fit for use in the production process and is earmarked for such purpose in the appropriate economic plan.

As a consequence of the legal duty of national enterprises to utilize national property according to plan, such property is as a rule not subject to their disposition by title transaction. ${ }^{12}$ A different rule obtains for public assets which serve a purpose necessarily including the right of disposal. This is especially the case with monetary funds and finished products manufactured by the enterprise itself. On the other hand, the principle of utilization according to plan here usually excludes the utilization of such properties than for any purpose other than disposal by property transaction.

\section{Accounting and enterprise policy}

The managerial and legal independence of national enterprises is inseverably linked to their obligation to utilize national property in accordance with the economic plan. They are consequently obliged to make use of public property economically, in accordance with the principle of optimum return, and by the applica-

\footnotetext{
${ }^{10}$ Decree concerning measures for the introduction of the principle of economic accounting, op. cit. supra note $9, \S I$, para. I.

${ }^{11}$ M. Posch (Ed.), Das Zivilrecht der Deutschen Demokratischen Republik, Sachentecht 55 (I956).

${ }^{12}$ See Regulation concerning transactions involving movable national basic assets and the registration of title to national real property, of Sept. 8, 1958, [1958] I GBl.DDR 697, which contains a number of special provisions pertinent in this connection.
} 
tion of the economic accounting system. ${ }^{13}$ - This system requires that national enterprises cover all expenditures arising in the course of their operations out of their income from the disposal of their products, and achieve the gain envisaged by the economic plan. Every national enterprise organizes its production processes and plans its entire activities in accordance with this objective of management policy. Economic accounting encourages the managerial staffs to lower production costs and increase net returns from production. ${ }^{14}$ In the exercise of this function of furthering production efficiency, the works management is aided by its authority to use a portion of net returns for premiums in reward of superior performance and for additional social and cultural functions of the enterprise itself, thus giving employees and labor force a material stake in the success of the enterprise. ${ }^{15}$

The economic accounting system would be unthinkable without the managerial and legal independence of national enterprises. Its effectiveness decisively depends upon improvements in the planning and organization of internal production processes through the responsible participation of the workers and employees of the enterprise itself.

\section{Contractual relations}

One important function of managerially and legally independent national enterprises is the establishment of contractual relations with other national enterprises, cooperatives, or privately owned enterprises, for sales and supplies called for by the economic plan. A more detailed discussion of the "contract law" which governs these contractual relations ${ }^{16}$ would exceed the confines of the present discussion. The basic function of the so-called "contract system" between national enterprises is the coordination of the tasks of the contracting parties by interrelating the timing and substantive contents of supplies and deliveries, thus giving more explicit expression to the economic task pursued while at the same time safeguarding its attainment. A concomitant of this basic purpose of the contract system is the legal duty of national enterprises to conclude contracts with each other for the supply or the purchase of goods and for the securing or the performance of services, when-

${ }^{13}$ See generally, Decree concerning measures for the introduction of the principle of economic accounting, op. cit. supra note 9 .

14 Academy of Sciences of the U.S.S.R., Institute of Economics, Political Economy 6r7740 (3d ed. 1958; German translation I959).

${ }_{15}$ Decree concerning the director's account in national enterprises, of Jan. 26, I956, [1956] I GBl.DDR 129, as amended; Decree concerning Enterprise Premium Funds and Cultural and Social Funids, of May 11, 1957, [1957] I GBl.DDR 289, as implemented by Regulation of June 25, 1957, id. at 358 , and as amended by Decree of Aug. 28, 1958, [1958] I id. at 66r; Regulation concerning the financing of cultural, social, health, training, and other expenses of national enterprises, of Jan. 4, 1956, [1956] II id. at 21, as revised id. at I26; Regulation concerning funds and vouchers for expenses in the training of apprentices of national enterprises, of Oct. 25, I956, [1956] I id. at II49.

${ }^{10} \mathrm{Law}$ concerning the contract system in the socialist economy (Contract Law), of Dec. II, I957, [1957] I GBI.DDR 627. The Contract Law contains special regulations governing contractual relationships between national enterprises. The provisions of the Civil Code apply only in the absence of pertinent rules of the contract law. See generally, J. Hemmerting (Ed.), GrundLANGen der VerTRAGSSYSTEMS (1958). 
ever such contractual relationships become necessary in the execution of the economic plan. ${ }^{17}$

\section{Legal capacity and scope thereof}

The legal status of national enterprises as managerially and legally independent economic state organs is further reflected by their duty to realize their objectives solely through the utilization of property subject to their jurisdiction, and by the liability of this property for the fulfillment of all valid obligations of the enterprise.

The independent participation of national enterprises in legal relationships and their concomitant independent liability necessarily entail their ability to create rights and obligations by their own actions, i.e., their "legal personality," or capacity. This capacity is conferred upon each national enterprise by the state at the time of its creation. ${ }^{18}$.

A problem of substantial practical importance is the scope of the legal capacity of national enterprises. This is delimited by the tasks of the individual national enterprise, and is reflected by (I) the legal instrument of their creation, the Statut, ${ }^{10}$ (2) the plan tasks laid down by the state; and (3) pertinent special regulations of the organs of economic supervision. In view of the tremendous variety of tasks performed by the various national enterprises, and of further differences of the special tasks allotted to each enterprise, a general statement of the scope of the capacity of national enterprises seems hardly possible. In individual cases, however, this scope can be determined without difficulty. The only generalization possible in this connection is the statement that national enterprises are empowered to acquire all rights and incur all liabilities necessary for the orderly accomplishment of the tasks given to them by the state.

Rights and obligations exceeding the scope of the tasks allotted to each individual national enterprise by the State cannot validly be created. All legal actions purporting to establish such rights and obligations are void. ${ }^{20}$

The delimitation of the scope of the legal capacity of national enterprises, with consequences as described above, is a peculiarity of the legal status of these enterprises. It safeguards the utilization of national property according to the economic plan, and gives specific expression to the principle of the inviolability of national property which is implicit in the constitution of the German Democratic Republic. ${ }^{21}$

${ }^{17}$ Contract Law, op. cit. supra note $16, \$$ I. The peculiarities of relations between national cnterprises under the Contract Law made riecessary the creation of special Contract Courts charged with deciding the most important legal controversies arising in this area. See Decree concerning the State Contract Court, of Jan. 22, 1959, [1959] I GBl.DDR 83; Decree concerning procedure of the State Contract Courts, of even date, id. at 96 .

${ }^{18}$ Charter of centrally administered enterprises, op. cit. supra note 9 ; $c f$. KLEINE, op, cit. supra note 9, at 194 .

1. See, e.g., Regulation conicerning the charter of national road traffic enterprises, of Sept. 25, 1959, [1959] II GBl.DDR 278.

${ }_{20}$ See generally, KLEINE, op. cit. supra note 9, at 203; I D. M. Genkin, S. N. Bratus, L. A. Lunz \& I. B. Nowitzki, SowJetisches Zivilnechr I84-x85 (1950; German translation r953); Dawidowitsch, Die staatlichen juristischen Personen, [1952] Rechtswissenchaftlicher Informationsdienst, No. 7, p. 5 .

${ }^{21}$ German Democratic Republic Const. art. 28; English translation in Peaslee 64. 


\section{Management}

As a managerially and legally independent enterprise, each national enterprise is directed by a works director. The director individually manages the enterprise on his personal responsibility, and has the legal status of an officer of the enterprise. He has exclusive powers to represent his national enterprise in negotiations, and is empowered to sign contracts and other binding instruments on behalf of the enterprise. He also represents it in and outside of litigation. ${ }^{22}$

\section{IV}

\section{The Legal Nature of National ENterprises}

Statutory provisions concerning managerially and legally independent national enterprises as a rule refer to them as "legal entities" (juristische Personen). In the legal literature of the German Democratic Republic, legal entities are defined as organizations which are subjects of civil law and have legal capacity. Characteristics common to all legal entities are said to be their organizational structure as determined by law or "Statut"; the separation of their properties from that of the incorporators and members; and their separate liability in property matters. ${ }^{23}$

It is submitted that the theory of legal entities has the defects of an excessive and therefore practically worthless abstraction, and is essentially aimed at dealing with private organizations with legal capacity. The legal entity theory fails to reflect some essential elements of the regime of national enterprises, since it is exclusively concerned with proprietary relationships. This limitation leads to the neglect of factors which are indispensable for the correct appraisal of the legal status of national enterprises, such as the relations flowing from the central planning and directing activities of the state, and the participation of enterprise personnel in the direction of the production process.

${ }^{29}$ Charter of centrally administered enterprises, op. cit. supra note 9, $\$ 4$ and 5, paras. I, 2, and 4 .

${ }^{23}$ KLEINE, op. cit. supra note 9, at I90. 
